\title{
THE EXCHANGE RATE OF THE RUBLE IS CLOSE TO THE EQUILIBRIUM POINT ${ }^{1}$
}

\author{
A.Bozhechkova, P. Trunin
}

The balance of payments for 2015 shows an increasing surplus in the current account balance, which has resulted from the shrinking deficit in the balance of services, the investment income balance and wages, coupled with the decreasing surplus in the trade balance. The accelerated weakening of the ruble in real terms against the national currencies of the developing countries during some prolonged periods of time in 2014-2015 was triggered by the mounting geopolitical risks and the plummeting oil prices.

As follows from the RF balance of payments preliminary estimates for 2015 released by the Bank of Russia, the growth index displayed by the current account balance amounted to $\$ 65.8 \mathrm{bn}$, having increased by $12.7 \%$ on 2014. The trade balance's growth index declined by $23.2 \%$ (from $\$ 189.7 \mathrm{bn}$ to $\$ 145.6 \mathrm{bn}$ ) due to the general downfall of prices for major items of Russia's exports (Fig. 1). Over the past year, exports of goods declined by $31.8 \%$ (from $\$ 498 \mathrm{bn}$ to $\$ 340 \mathrm{bn})$. Meanwhile, the drop in imports of goods as a result of the ruble's plummeting exchange rate against major world currencies and the shrinking incomes of economic agents was even more dramatic, having shrunk in monetary terms over the past year by $37.0 \%$ (from $\$ 308 \mathrm{bn}$ to $\$ 194 \mathrm{bn}$ ). In

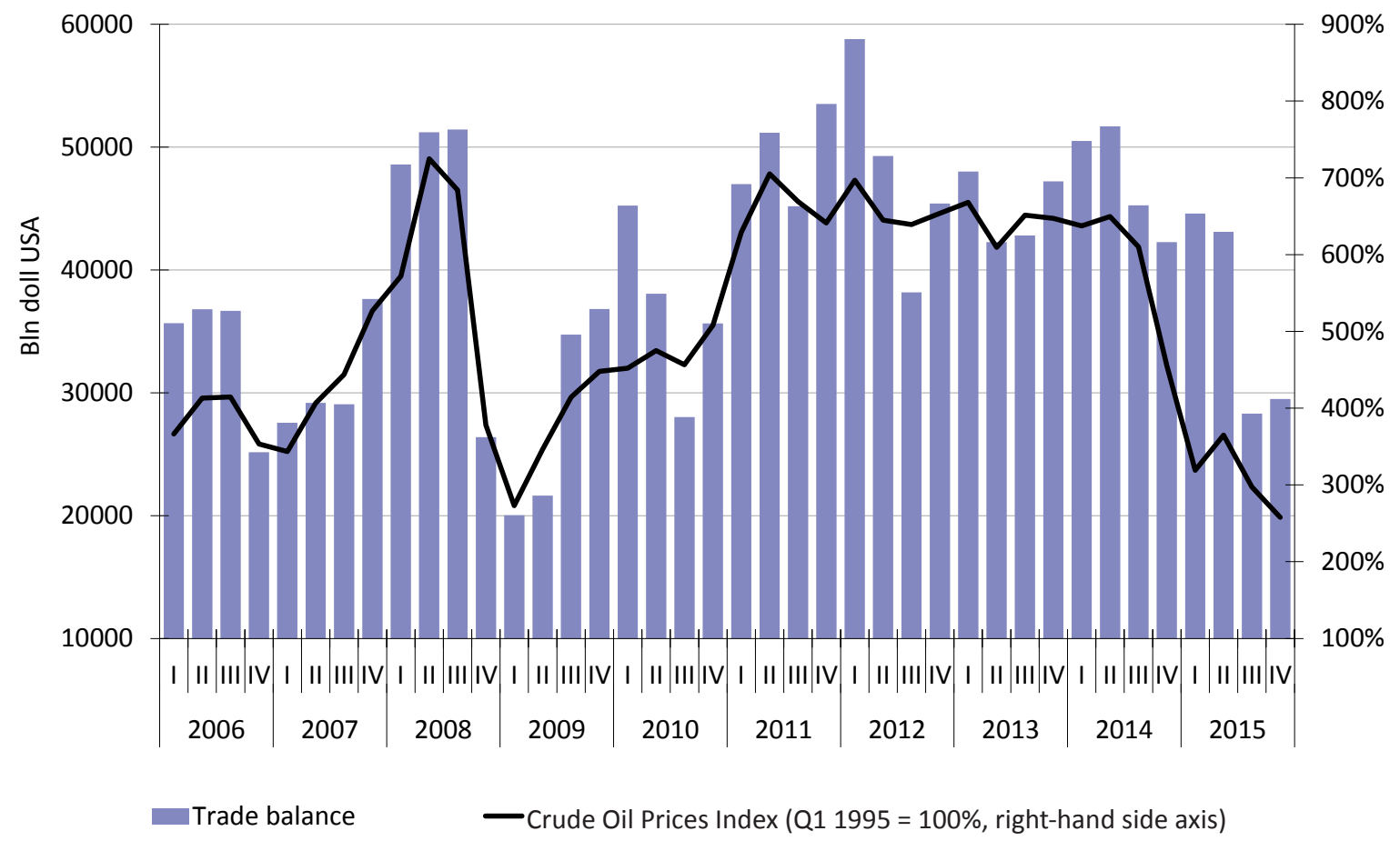

Source: Bank of Russia; EIA; estimates by the Gaidar Institute for Economic Policy.

Fig. 1. Russia's Balance of Trade and the Global Crude Oil Prices Index in 2006-2015

1 This paper was originally published in Online Monitoring of Russia's Economic Outlook No.2(20). 
all evidence, in 2016, imports will continue to decline at a significant rate in response to further weakening of the ruble in late 2015 and early 2016.

The current account balance increased, among other things, due to the shrinking deficits in the balance of services, the investment income balance, and the balance of wages. Thus, over 2015, the deficit in the balance of services had risen to $\$ 37.1 \mathrm{bn}$, and so shrank (in absolute terms) on the corresponding period of 2014 by $32.9 \%$. Imports of services over 2015 dropped on 2014 by $28.3 \%$ to $\$ 86.8 \mathrm{bn}$, due in the main to the fact that Russians had begun to spend less on foreign travel. The balance of wages over JanuaryDecember 2015 dwindled by $57.4 \%$, to $\$-4.3$ bn (vs. \$ -10.1 bn in 2014), most probably due to the shrinking wages of labor migrants, whose services had become much less in demand. In 2015, the deficit in the investment income balance declined on 2014 by $44.7 \%$, to $\$ 32.0 \mathrm{bn}$, which was mostly due to a notable decrease in expenditures on external debt servicing. Thus, in 2015, in spite of the breathtaking collapse in oil prices, the current account demonstrated a noteworthy rise in the inflow of foreign exchange relative to 2014.

As estimated by the Bank of Russia, over 2015, net capital outflow from the non-financial sector amounted to $\$ 56.9 \mathrm{bn}$, which is 2.7 times below the corresponding 12-month index for 2014. Over 2015, net capital export by banks rose to $\$ 33.4 \mathrm{bn}$, that by the private non-financial sector - to $\$ 23.5 \mathrm{bn}$. When adjusted by the index of banks' FX operations with the Bank of Russia, net capital outflow amounts to only $\$ 50.2 \mathrm{bn}$.

In 2015, Russia's banking sector continued to reduce the volume of its external liabilities; over the past year, this index dropped by $\$ 61.6 \mathrm{bn}$ (by $\$ 37 \mathrm{bn}$ in 2014). Over the same year, the non-banking sector reduced the volume of its external liabilities by $\$ 2.7 \mathrm{bn}$, while in 2014 this index had risen by $\$ 1$ bn.

The inflow of foreign direct investment (FDI) in Russia's non-banking sector amounted to $6.7 \mathrm{bn}$ vs. $\$ 18.5 \mathrm{bn}$ in 2014 , thus having reached its record low since 2003. The other types of their external liabilities (portfolio investments, loans and other liabilities) further shrank in 2015 by $\$ 9.5 \mathrm{bn}$, after their drop in 2014 by $\$ 17.8$ bn. It should be noted that, in 2015, the volume of scheduled repayments should have been $\$ 82.6 \mathrm{bn}$, but the actual shrinkage of external liabilities amounted to only $\$ 2.7 \mathrm{bn}$. Most likely, this situation can be attributed to intra-group transactions aimed at optimizing external debt management. In the course of such transactions, banks repay the debts due to intra-group creditors, who would then use the received funds to repay the 'real' external debt.

It should be reminded that, in Q3 2015, for the first time over a very long period of time, the Bank of Russia reported a net capital inflow into Russia's private sector which, if the banking sector's transactions with the regulator are taken into account, amounted to $\$ 1.8 \mathrm{bn}$. Previously, net capital inflow had been observed in Q2 2010 in the amount of \$ 4.1bn. Net capital inflow in Q3 2015 occurred due to the increasing external liabilities of the other sectors as a result of new loans, thus pointing to a certain palpable stabilization in the overall economic situation over that period.

Over 12 months of 2015, the foreign assets of residents (foreign economic agents' liabilities to Russian economic agents) decreased by $\$ 8.6 \mathrm{bn}$. (vs. growth by $\$ 81.3 \mathrm{bn}$ in 2014). Over the same period of time, the banking sector's foreign assets declined by $\$ 28.2 \mathrm{bn}$ (vs. growth by $\$ 48.5 \mathrm{bn}$ in 2014). It should be noted that, over January-September 2015, the decline in the 
volume of banks' foreign assets resulting from their FX-denominated transactions with non-residents amounted to $\$ 7.8 \mathrm{bn}$ (vs. growth by $\$ 50.4 \mathrm{bn}$ in 2014).

At the same time, as a result of their retail operations with the population, banks' foreign assets amounted to only $\$ 0.6 \mathrm{bn}$ (vs. \$ $-38.1 \mathrm{bn}$ in 2014). In other words, in 2015 the population displayed a much lower demand for foreign cash than a year earlier. As estimated by the Bank of Russia, over the first 9 months of 2015, the volume of foreign cash held by the population shrank by $\$ 11.8 \mathrm{bn}$, to $\$ 40.5 \mathrm{bn}$.

In 2016, the foreign assets held by Russia's private non-banking sector increased by only $\$ 17.8 \mathrm{bn}$ (vs. by $\$ 72.6 \mathrm{bn}$ in 2014 ). The deepest plunge in absolute terms was demonstrated by the index of Russian residents' direct overseas investment (from \$54.5bn in 2014 to $\$ 20.5 b n$ in 2015). Also noteworthy is the continuing downward trend displayed by the volume of dubious operations, which shrank by $\$ 2.8 \mathrm{bn}$ to $\$ 4 \mathrm{bn}$.

The decline in the volume of capital outflow was caused, among other things, also by the Bank of Russia's policy, when the regulator chose to abstain from interventions in the FX market and to switch over to a freely floating foreign exchange rate of the national currency. As demonstrated by the 12-month period-end result of 2015, as of the beginning of January 2016, Russia's international reserve assets shrank by $\$ 17.1$ bn $(-4.4 \%)$ to $\$ 368.4 \mathrm{bn}$. Over 2015 , the volume of foreign exchange reserves declined by $\$ 19.9 \mathrm{bn}(-5.9 \%)$, due in the main to the foreign exchange repo operations with banks. The monetary gold reserves over the same period increased by $\$ 2.5$ bn (+5.4\%) on their index as of the year's beginning, which was the result of gold purchases by the Bank of Russia.

Over the course of 2015, these developments pushed up the official USDto-ruble exchange rate by $12.9 \%$ - from the average index of $\mathrm{Rb} 61.7$ for

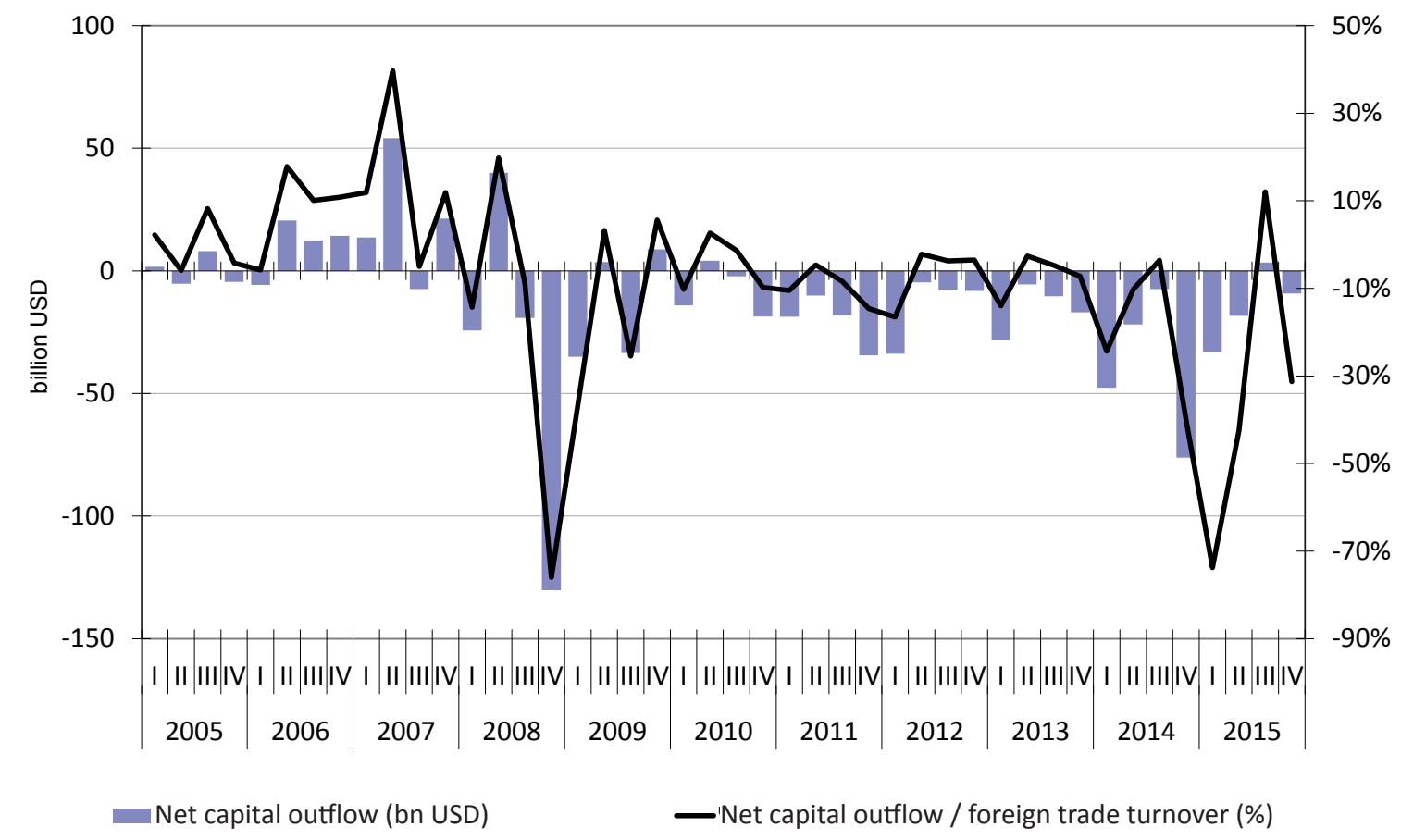

Sources: Bank of Russia; estimates by the Gaidar Institute for Economic Policy.

Fig. 2. Net Capital Outflow in 2005-2015 
January 2015 to $\mathrm{Rb} 69.7$ for December 2015. At the same time, the average euro-to-ruble exchange rate for December 2015 amounted to $\mathrm{Rb} 75.8$, having increased over the year by $4.4 \%$.

In January 2016, due to the ongoing plunge of oil prices, the ruble-to-USD exchange rate declined by $4.7 \%$, from $\mathrm{Rb} 72.9$ to $\mathrm{Rb} 76.3$; over the same period, the euro-to-ruble exchange rate rose by $4.0 \%$ to $\mathrm{Rb} 82.8$, while the value of the bi-currency basket increased by $4.3 \%$ to $\mathrm{Rb} 79.2$. As a result, on 22 January, the official USD-to-ruble exchange rate hit its record high of $\mathrm{Rb} 83.6$.

It is noteworthy that, according to our estimations, the pass-through effects of the ruble's exchange rate decline in Russia's sector of consumer goods amounts to between $10 \%$ and $20 \%$ depending on a particular foreign currency and the observation period. In other words, the ruble's weakening by $14.4 \%$ over December 2015 - January 2016 will translate into an additional growth of the inflation rate by 1.4-2.9 p.p. in 2016.

In spite of the declining prices for Russia's major exports and the ruble's depreciation in nominal terms, the high inflation rate in Russia over the 12 -month period of 2015 pushed up the national currency's real effective exchange rate by $1 \%$ (over 2014 , it had shrunk by $27.4 \%$ ) to its December 2014 level, which also corresponds to its index for January 2005.

An analysis of the variances in the movement of the real ruble-to-USD exchange rate (based on such data as consumer price indexes (CPI), producer prices, and the average monthly charged wage in nominal terms) demonstrates that the competitive capacity of Russian goods in the world market is on the rise (Fig. 3). As of November 2015, the base ruble-to-USD exchange rate in real terms (calculated with due regard for the relative movement of wages in Russia and the USA) was 1.5 times below the same index calculated on the basis of CPIs estimated in relative terms. These findings indicate that the competitive potential of Russian producers has been increasing in the current crisis situation due to the shrinkage of the wage component of their costs.

In general, over the period 2014-2015, the plunge of the ruble's real effective exchange rate was much deeper than that of the national curren-

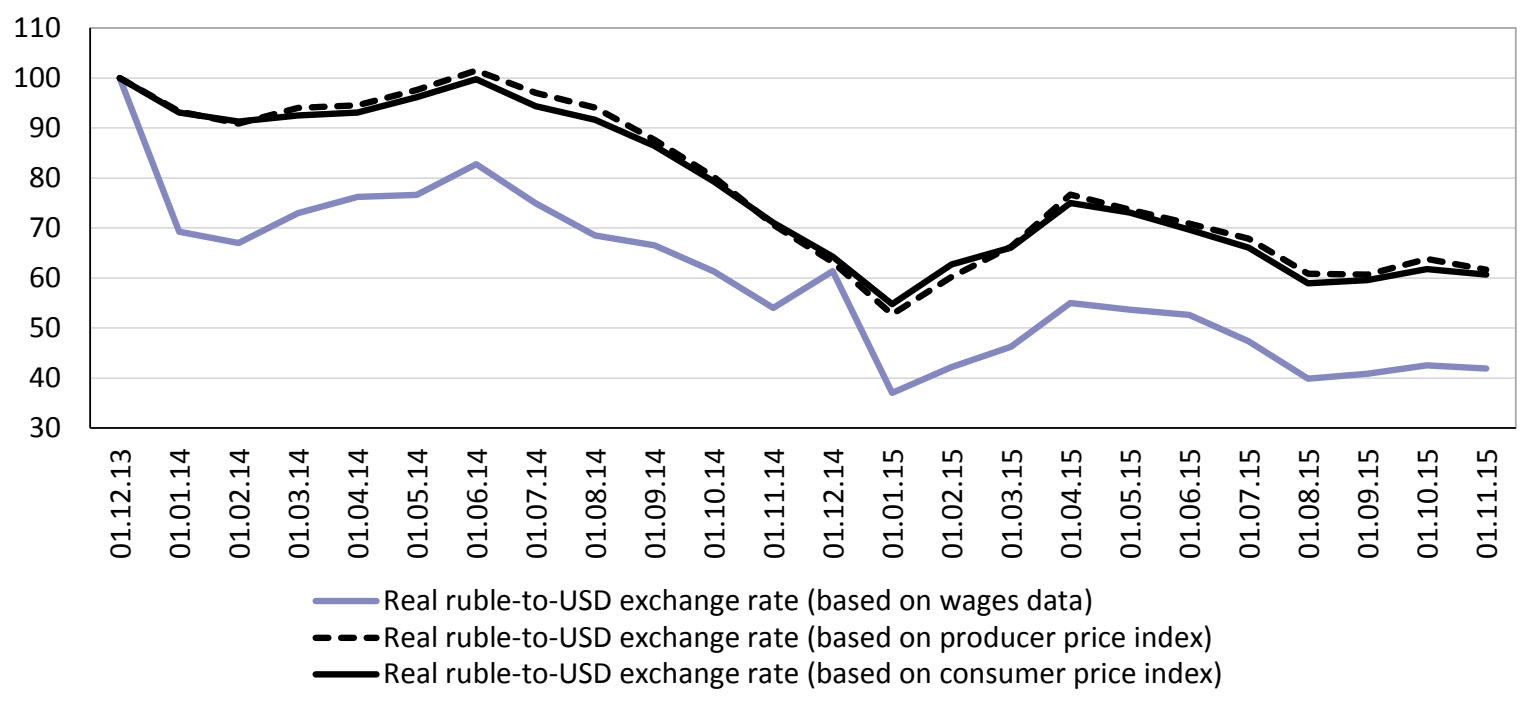

Sources: OECD; Bank of Russia; Rosstat; authors' calculations.

Fig. 3. The Real Ruble-to-USD Exchange Rate Movement Based on Different Price Indexes (December 2013=100\%) 


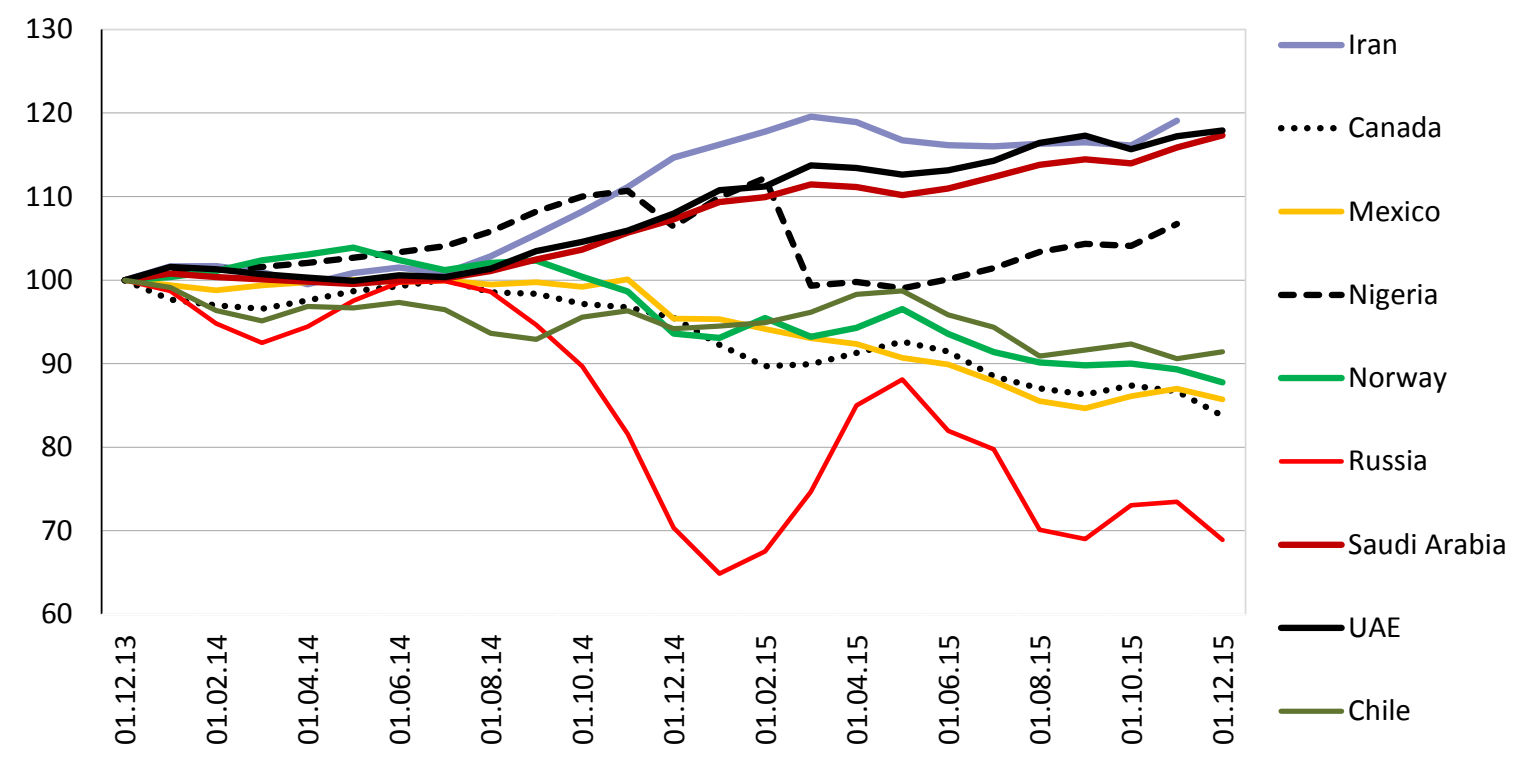

* data for Iran and Nigeria are for the period from January 2014 through November 2015.

Sources: BIS; International Financial Statistics (IMF); authors' calculations.

Fig. 4. The Movement of Real Effective Rates of the National Currencies of Countries -Exporters of Raw Materials, 2014-2015 (December 2013=100\%)

cies of the other countries -major exporters of raw materials. For reference: over the period 2014-2015, the real effective exchange rate of the Russian ruble dropped on December 2013 by 31.1\%, that of the Norwegian krone by $12.2 \%$, that of the Canadian dollar by $16.3 \%$, and that of the Mexican peso by $14.3 \%$ (Fig. 4). The fact that the depreciation rate of the Russian ruble in the second half year of 2014 and over June-September 2015 was so high in real terms can be explained, among other things, by the mounting geopolitical risks and the international economic sanctions introduced against the Russian Federation.

The ruble's real effective exchange rate is currently hovering around its point determined by fundamental factors, this situation being an upshot of the natural behavior of the foreign exchange market, without any interference on the part of the Bank of Russia or the effects of a panic among economic agents. In absence of any new shocks, we do not expect any further dramatic plunges of the national currency's exchange rate. 